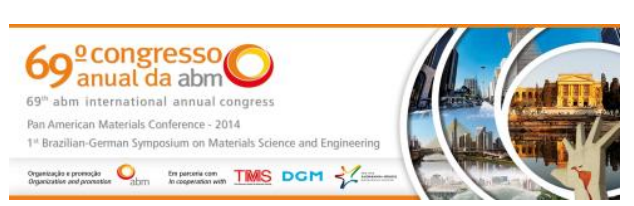

Theme: Ceramic, Composite and Polymeric Materials

\title{
DEVELOPMENT AND CHARACTERIZATION OF COMPOSITE-COATED INTERCONNECTS FOR USE IN HIGH AND INTERMEDIATE TEMPERATURE FUEL CELLS*
}

\author{
Ananda Moreira Vaz Ourique de Avila ${ }^{1}$ \\ Rodrigo Dias ${ }^{2}$ \\ Roberta Martins de Santana ${ }^{3}$ \\ José Geraldo de Melo Furtado ${ }^{4}$
}

\begin{abstract}
High and intermediate temperature fuel cells (FC) are power generators characterized by high efficiency and their use in cogeneration systems. The single fuel cells are connected in series by the use of interconnects to form a fuel cell stack. Ferritic stainless steels have been used in the making of high and intermediate temperature operation solid oxide fuel cells interconnects. However, at high temperatures, on the order of $700-850^{\circ} \mathrm{C}$, these steels can present significant oxidation and degradation processes, promoting increased electrical resistivity and corrosion losses that result in contamination of the electrodes and reducing the performance and the useful life of the FC. Intensive R\&D activities have been made to minimize these problems and the use of composite coatings on metallic substrate has been considered. This paper evaluates the use of coatings of copper and nickel, with particles of $\mathrm{La}_{2} \mathrm{O}_{3}, \mathrm{Y}_{2} \mathrm{O}_{3}, \mathrm{CeO}_{2}, \mathrm{LaCrO}_{3}$ and doped chromites applied on ferritic stainless steels AISI 430, AISI 441 and Crofer22APU produced by electrodeposition. The produced samples were evaluated by microscopy techniques, gravimetric analysis and by electrothermal characterization. The most significant results were obtained with chromites coatings ( $\mathrm{LaCrO}_{3}$ pure, mono- and multiple-doped) showing the combination of the best features of metal coatings, substrates and ceramic particles with semiconductor properties.
\end{abstract}

Keywords: Fuel cells; Composite interconnects; Ferritic stainless steels; Electrodeposition process.

\footnotetext{
Bachelor of Science, Fellow Researcher, DTE, CEPEL, Rio de Janeiro, RJ, Brazil. Bachelor of Science, Laboratory Technician, DTE, CEPEL, Rio de Janeiro, RJ, Brazil. Bachelor of Science, Laboratory Technician, DLF, CEPEL, Rio de Janeiro, RJ, Brazil. Doctor of Science, Researcher, DTE, CEPEL, Rio de Janeiro, RJ, Brazil.
}

\footnotetext{
* Technical contribution to the 69th ABM International Annual Congress and to the ENEMET, July $21^{\text {st }}-25^{\text {th }}$, 2014, São Paulo, SP, Brazil.
} 


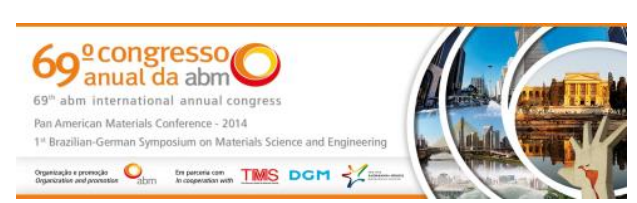

\section{INTRODUCTION}

Fuel cells are electrochemical devices that, via electrochemical reactions, are able to combine a fuel and an oxidant agent, converting the stored chemical energy of the fuel directly into direct-current electrical energy and heat as a byproduct. The fuel is not burned (there is no combustion), such as in a flame, as in conventional power generation systems (e.g. internal combustion engines - ICEs, turbines); rather, it is electrochemically oxidized. Thus, the maximum efficiency of a fuel cell is not limited by the thermo-mechanical cycle conversion processes, which limits many conventional power systems such as the internal combustion engines, steam and gas turbines, and heat pumps [1]. Thus, fuel cells have been regarded as the main power generation equipment capable of increasing the energy conversion efficiency and reduce or eliminate the emission of pollutants in various fields of applications [1-3].

Solid oxide fuel cell (SOFC), one of the types of fuel cells, is one of the most promising technologies for the production of energy, with potential to be a typical future distributed cogeneration system (CHP, combined heat and power) $[4,5]$ due to it high energy efficiency, low pollutant emissions, potential fuel flexibility, high modularity as a solid-state device and co-generation capability [5,6]. Typically, a SOFC system is constituted of at least seven distinct components [6-8]: fuel feed, anode, electrolyte media (separating the two electrodes), cathode, oxidant agent feed (normally air), sealing materials and electrical interconnects (completing the electrical circuit stack) as schematically showed in the Figure 1.
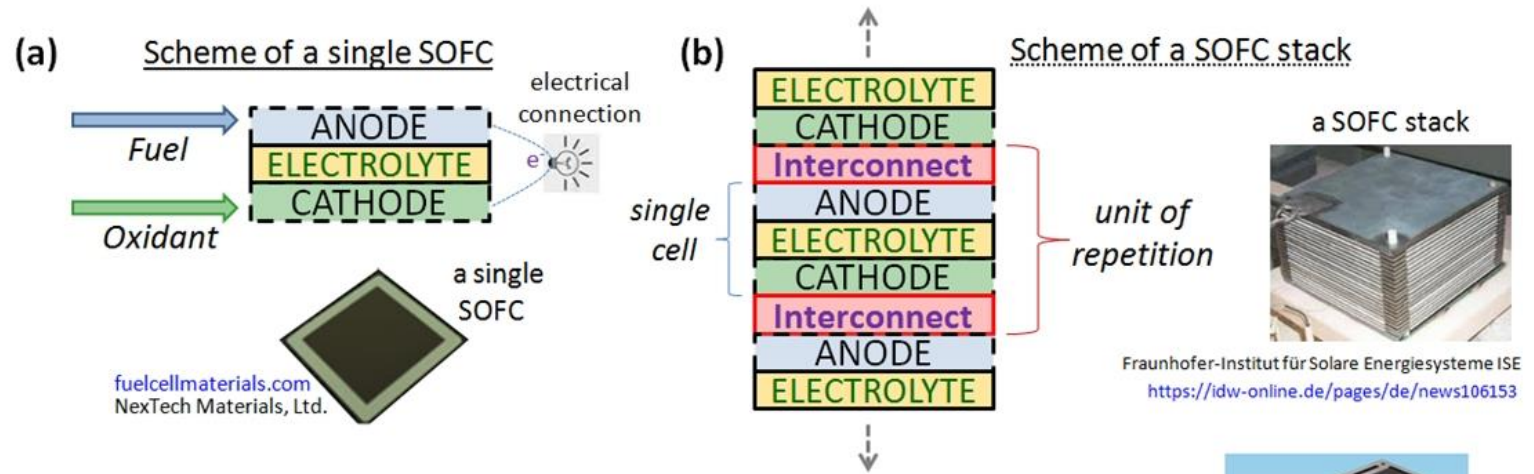

(c)

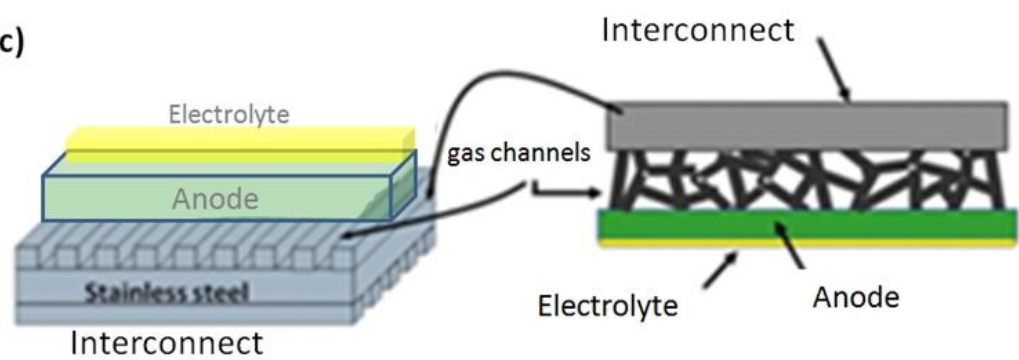

(d)

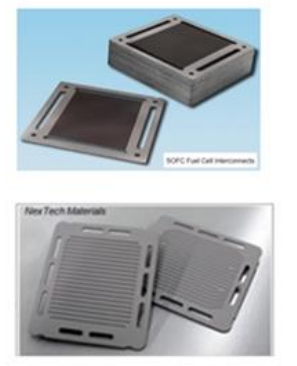

Figure 1. (a) Schematic diagram and example of a single SOFC; (b) scheme of the connection of the anode of a single SOFC to the cathode of the subsequent single SOFC, constituting a solid oxide fuel cell stack; (c) scheme of a electrolyte-anode bilayer supported on a metallic interconnect; (d) examples of SOFC interconnects.

In this work, the focus is on the interconnect. It is this component that lets connect the single SOFCs (individual cells) forming stacks (Figures 1(a) and 1(b)). In the last years, there is a greater tendency to develop the planar configuration for SOFC

\footnotetext{
* Technical contribution to the $69^{\text {th }} A B M$ International Annual Congress and to the ENEMET, July $21^{\text {st }}-25^{\text {th }}$, 2014, São Paulo, SP, Brazil.
} 
systems, and this type of configuration is capable of achieving very high power density $[8,9]$, characterized by a very thin Electrolyte-Electrodes Assembly (EEA) deposited on an interconnect considerably thicker, but that presents a zone for gas feeding (Figure 1(c)) [6,9]. Another interconnector closes the device and this set constitutes the repeating unit which is forming the stack. Figure 1 (d) shown examples of SOFC interconnects.

Under the SOFC operating environments, interconnect must exhibit excellent electrical conductivity (to minimize ohmic losses) with preferably nearly $100 \%$ electronic conduction, since interconnect provides the conductive path for electrical current to pass between the electrodes and to the external circuit. A value of $1 \mathrm{~S} / \mathrm{cm}$ is a well-accepted minimum electrical conductivity for the usefulness of interconnects in SOFC [6,7].

Interconnect should have adequate stability in terms of dimension, microstructure, chemistry, and phase at operating temperature around $700-850{ }^{\circ} \mathrm{C}$ in both reducing and oxidizing atmospheres, since they are exposed to oxygen on one side and fuel on the other. Interconnect should display exceptionally low permeability for oxygen and hydrogen to minimize the crossover direct combination of oxidant and fuel during cell operation. Thermal expansion coefficient (TEC) of interconnect should be comparable to those of electrodes and electrolyte between ambient and operating temperatures, so that the thermal stress developed during stack startup and shutdown could be minimized. No reaction or inter diffusion between interconnect and its adjacent components, specifically, anode and cathode, is allowed to occur under operation conditions. Interconnect should possess fairly good thermal conductivity ( $5 \mathrm{~W} / \mathrm{m} . \mathrm{K}$ is considered to be the low limit) $[5,7]$.

Excellent oxidation, sulfidation and carburization resistances are required attributes for interconnect to qualify for application in SOFC-like environments. In addition, cost-effective manufacture of fuels cells requires that the interconnect materials be easy to fabricate. The costs of raw materials as well as manufacture processes for interconnect are also supposed to be as low as possible so that they will not present hurdles to commercialization. Finally, interconnect should also show adequate high temperature strength and creep resistance. This requirement is of special relevance to the planar SOFC where interconnect serves as a structural support.

With the possibility of reducing the operating temperature of $900{ }^{\circ} \mathrm{C}-1,000^{\circ} \mathrm{C}(\mathrm{HT}-$ SOFC, high temperature SOFC) to $650^{\circ} \mathrm{C}-800^{\circ} \mathrm{C}$ (IT-SOFC, intermediate temperature SOFC) due to development of new materials and constructive refinements of the device that allowed the employment electrolyte reduced thicknesses, which do not require temperatures as high as those of the firstgeneration of SOFC, it became possible to use metal interconnects to replace the purely bulk ceramic interconnects based on lanthanum chromites, the which can represent significant gains in manufacturing (via simplification of procedures) and operating performance of SOFC $[7,8,10]$.

Thus, in recent years, ferritic stainless steels (FSS) have been intensively considered for this application [5,8-12]. However, about $800^{\circ} \mathrm{C}$, FSS have problems caused by volatilization of $\mathrm{Cr}$ contained therein and the overgrowth of chromium oxide $\left(\mathrm{Cr}_{2} \mathrm{O}_{3}\right)$ layer, with high electrical resistivity, which tends to increase the electrical contact resistance (ECR) between the interconnector and the SOFC electrodes, causing loss of performance and promoting the degradation of the device.

A solution that has been proposed is to coat the stainless steel with metals, such as nickel, cobalt, or copper, also incorporating rare earth oxides (such as Ce, La, Y) particles $[8,10]$. The metallic layer, which immediately oxidizes completely the case

\footnotetext{
* Technical contribution to the $69^{\text {th }} A B M$ International Annual Congress and to the ENEMET, July $21^{\text {st }}-25^{\text {th }}$, 2014, São Paulo, SP, Brazil.
} 
for $\mathrm{NiO}, \mathrm{CuO}$ and $\mathrm{CO}_{3} \mathrm{O}_{4}$, which are semiconductors and exhibit good electrical conductivity at $800{ }^{\circ} \mathrm{C}$, acts as a barrier to volatilization of $\mathrm{Cr}$ from the FSS substrate. Rare earth oxides (also compound semiconductor) incorporated into the layer, even in small amounts, reduce the growth of the $\mathrm{Cr}_{2} \mathrm{O}_{3}$ layer, improve their adhesion to the substrate and decrease the degradation of the electrical contact, by the oxidation that occurs over time [8]. Comprehensive reviews about coatings on metallic interconnects can be found in the works of Shaigan et al. [8] and Wu and Liu [10].

Whatever the fabrication process of the interconnectors, the characterization of two basic parameters is critical to evaluate the performance of this SOFC component: (1) the determination of the parabolic oxidation constant (kp) by conducting the thermogravimetric tests and (2) the determining the specific electrical resistance per unit area (ASR) by means of electrical measurements. Additionally, other parameters may also be considered for the evaluation of materials for SOFC interconnects, namely (3) the thickness of the chromium oxide layer, which can be determined by microscopy or estimated from knowledge $\mathrm{kp}$, (4) the amount of volatilized chromium (gaseous species type $\mathrm{Cr}^{6+}$ ), which is generally obtained from chemical analyzes involve the collection of gases emanating from the heating material, and (5) the coefficient of thermal expansion (CTE), which is an important parameter that affects the assembly and operation of the stack, since the components of the SOFC should provide CTE values very close in order to minimize the occurrence failures from thermal origin that can result in structural collapse of the device $[5,8]$.

In this context, in the present study, the use of composite coatings of copper and nickel, with particles of $\mathrm{La}_{2} \mathrm{O}_{3}, \mathrm{Y}_{2} \mathrm{O}_{3}, \mathrm{CeO}_{2}, \mathrm{LaCrO}_{3}$ and doped chromites (LCSCM) applied by electrodeposition on ISI 430, AISI 441 and Crofer22APU ${ }^{\circledR}$ ferritic stainless steels, was evaluated by gravimetric test, microscopic and electrothermal analyzes. The substrates (FSS) chosen are representative of the universe of metallic materials that have been considered for use in SOFC: AISI 430 is a ferritic alloy which is one of the corrosion resistant steel used for industrial application at high temperatures, AISI 441 is the most that has been considered for use in SOFC interconnects and Crofer22APU ${ }^{\circledR}$ is a FSS that has been specially developed for this application under high temperature $[8,10]$.

\section{MATERIAL AND METHODS}

The metal samples of AISI 430, AISI 441 and Crofer22APU ${ }^{\circledR}$, with $15 \mathrm{~mm}$ (length) $\mathrm{x}$ $10 \mathrm{~mm}$ (width) $\times 1 \mathrm{~mm}$ (thickness) were prepared from the respective original plates of $1 \mathrm{~mm}$ thickness by cutting and grinding with 600\# and 1200\# metallographic sandpapers. These samples were coated by electrodeposition with a layer of $7 \mu \mathrm{m}$ to $10 \mu \mathrm{m}$ of $\mathrm{Ni}$ or $\mathrm{Cu}$ in baths of nickel sulfate or copper sulfate, respectively. The concentration of particulate oxides $\mathrm{La}_{2} \mathrm{O}_{3}, \mathrm{Y}_{2} \mathrm{O}_{3}, \mathrm{CeO}_{2}, \mathrm{LaCrO}_{3}$ and $\mathrm{LCSCM}$ suspended in baths was $(30.0 \pm 0.5) \mathrm{g} /$ liter. The choice of deposition parameters such as the exact composition of the baths, $\mathrm{pH}$, temperature and electrical current density was performed by experimentation, seeking to obtain layers with low porosity, which does not present spalling or losing of the composite coating and to provide proper incorporation of particles of oxides. In general, the electrodepositions of $\mathrm{Ni}$ were performed at $50^{\circ} \mathrm{C}$ and $\mathrm{pH} 6.0$, while electrodepositions of $\mathrm{Cu}$ were carried out at room temperature and $\mathrm{pH}$ 3.5. In Figure 2 are shown some sample specimens, different configurations of sample holder, part of the experimental apparatus used in the electrodeposition process in the laboratory and two suspensions that were employed. The LCSCM $\left(\operatorname{La}(1-x-y) X_{(x)} Y_{(y)} \operatorname{Cr}_{(1-z)} Z_{(z)} O_{3}\right)$ ceramics were synthesized and

\footnotetext{
* Technical contribution to the $69^{\text {th }} A B M$ International Annual Congress and to the ENEMET, July $21^{\text {st }}-25^{\text {th }}$, 2014, São Paulo, SP, Brazil.
} 

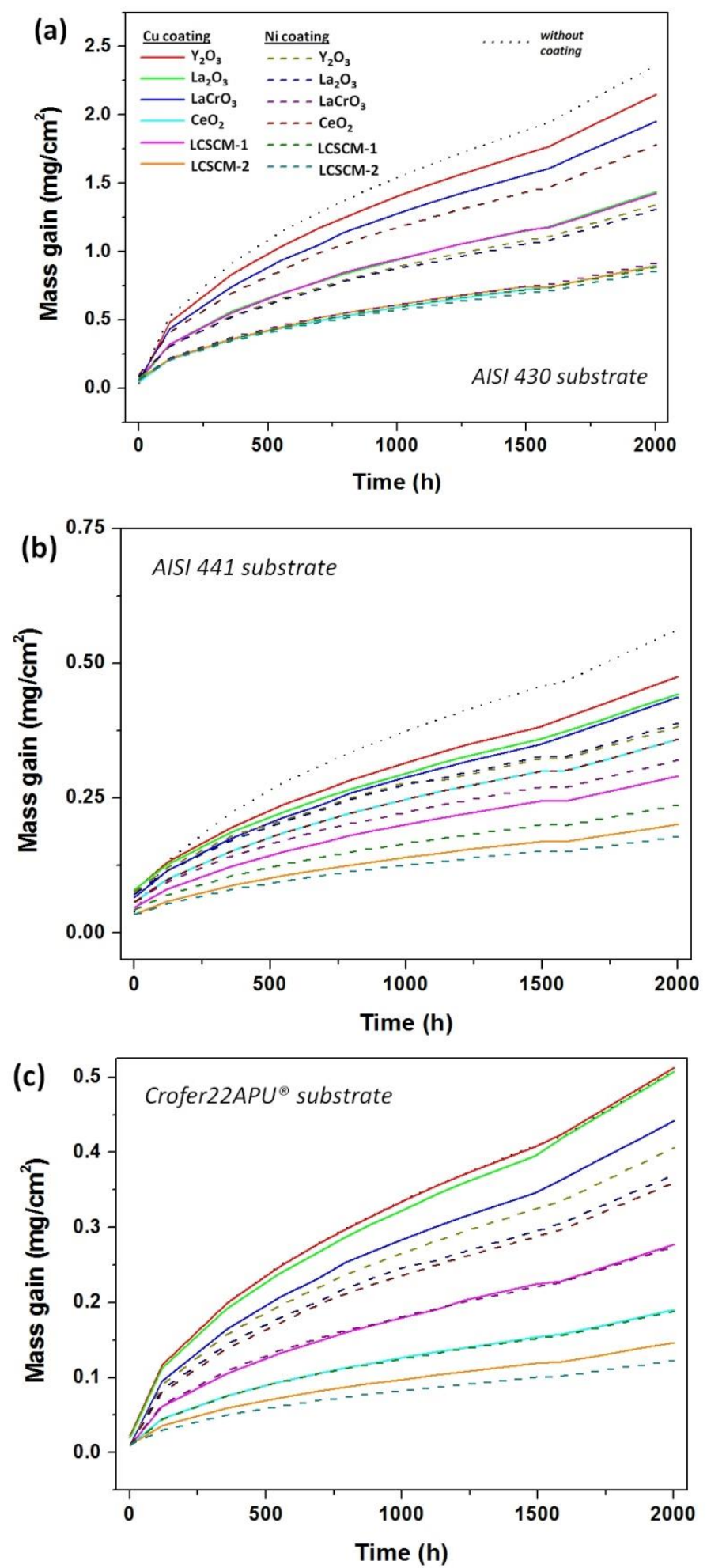

Figure 3. Results about the mass gain of studied samples with metallic substrates (FSS) for 2,000 hours of air oxidation testing to $800^{\circ} \mathrm{C}$ : (a) AISI 430; (b) AISI 441; (c) Crofer22APU.

From these graphs, we note that the mass gains for all samples having AISI 430 as substrate are significantly higher when compared to systems based on AISI 441 or Crofer22APU ${ }^{\circledR}$, four to five times in general. Furthermore, although for the three substrates the best results in terms of mass gain kinetic behavior during the oxidation (less mass gain) have been obtained by Ni/LCSCM-2 coating, for the other combinations of metallic coating, and ceramic particles, the orders were not same. In

* Technical contribution to the $69^{\text {th }} A B M$ International Annual Congress and to the ENEMET, July $21^{\text {st }}-25^{\text {th }}$, 2014, São Paulo, SP, Brazil. 


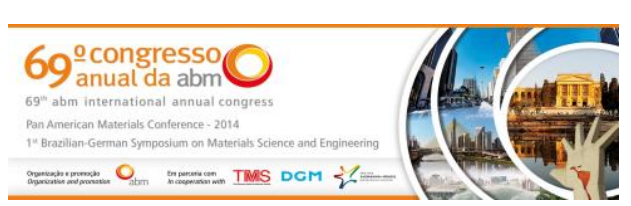

fact, in an overview, the combinations of metal ( $\mathrm{Ni}$ or $\mathrm{Cu}$ ) with the doped chromites (LCSCM-1 or LCSCM-2) resulted in curves that showed the best behaviors in terms of mass gain for Crofer22APU ${ }^{\circledR}$ and AISI 441 substrates, most notably for the latter.

But for the AISI 430 substrate, this was not so significant, since, for example, $\mathrm{Cu} / \mathrm{LCSCM}-1$ system is not among the top results, which showed less behavior than the $\mathrm{Cu} / \mathrm{CeO}_{2}$. In general, the best results in terms of the behavior associated with the minimization of mass gain were obtained for the Crofer22APU ${ }^{\circledR}$ and AISI 441 coated with Ni/LCSCM-2, Cu/LCSCM-2 and Ni/LCSCM-1 systems. Interestingly, although resulting in higher values of mass gain, these were also the best coatings to the substrate AISI 430.

These results indicate more effective contributions of doped lanthanum chromites to minimize the growth of chromium oxide layer, thus corroborating other results in the literature [4,11]. In fact, the $\mathrm{kp}$ values presented in Table 1 clearly show that the systems Crofer22APU ${ }^{\circledR}-\mathrm{Ni} / \mathrm{LCSCM}-2$ and Crofer22APU ${ }^{\circledR}-\mathrm{Cu} / \mathrm{LCSCM}^{-2}$ were those with the lowest values.

Table 1. $\mathrm{k}_{\mathrm{p}}$ parameter values (parabolic oxidation constant) for the studied systems

\begin{tabular}{|c|c|c|c|}
\hline \multirow[t]{2}{*}{$\mathrm{k}_{\mathrm{p}}\left(\mathrm{g}^{2} \cdot \mathrm{cm}^{-4} \cdot \mathrm{s}^{-1}\right) \times 10^{-14}$ * } & \multicolumn{3}{|c|}{ Substrate - Ferritic Stainless Steel (FSS) } \\
\hline & AISI 430 & AISI 441 & Crofer $22 \mathrm{APU}^{\circledR}$ \\
\hline Uncoated & 187 & 8.45 & 6.23 \\
\hline \multicolumn{4}{|l|}{ With the coatings below: } \\
\hline $\mathrm{Ni} / \mathrm{La}_{2} \mathrm{O}_{3}$ & 14.40 & 1.70 & 1.49 \\
\hline $\mathrm{Ni} / \mathrm{CeO}_{2}$ & 23.52 & 1.33 & 0.93 \\
\hline $\mathrm{Ni} / \mathrm{Y}_{2} \mathrm{O}_{3}$ & 18.50 & 1.89 & 1.62 \\
\hline $\mathrm{Ni} / \mathrm{LaCrO}_{3}$ & 10.14 & 0.98 & 0.45 \\
\hline $\mathrm{Ni} / \mathrm{LCSCM}-1$ & 9.03 & 0.89 & 0.41 \\
\hline $\mathrm{Ni} / \mathrm{LCSCM}-2$ & 8.75 & 0.51 & 0.20 \\
\hline $\mathrm{Cu} / \mathrm{La}_{2} \mathrm{O}_{3}$ & 21.12 & 2.11 & 2.16 \\
\hline $\mathrm{Cu} / \mathrm{CeO}_{2}$ & 9.30 & 0.62 & 0.31 \\
\hline $\mathrm{Cu} / \mathrm{Y}_{2} \mathrm{O}_{3}$ & 43.80 & 2.23 & 2.98 \\
\hline $\mathrm{Cu} / \mathrm{LaCrO}_{3}$ & 36.85 & 2.01 & 1.91 \\
\hline Cu/ LCSCM-1 & 18.45 & 1.14 & 1.05 \\
\hline Cu/ LCSCM-2 & 10.12 & 0.68 & 0.29 \\
\hline
\end{tabular}

* The values of $\mathrm{kp}$ are of the type $M \times 10^{-14}$, where $M$ is the value read from the table.

These aspects related to the formation and growth of chromium oxide layers in steels are of fundamental importance for its use as the basis of the fuel cell interconnectors. Thus, based on the results of mass gain as a function of oxidation time, the curves (such as the of Figure 3) can be represented by equations parabolic growth of the type:

$$
(\Delta \mathrm{M} / \mathrm{S})^{2}=\mathrm{k}_{\mathrm{o}}+\mathrm{kp} . \mathrm{t}
$$

Where, $\Delta \mathrm{m}[\mathrm{g}]$ is the mass gain, $\mathrm{S}\left[\mathrm{cm}^{2}\right]$ is the area exposed to oxidation, $\mathrm{k}_{\mathrm{o}}$ is a constant $\left[\mathrm{g}^{2} \cdot \mathrm{cm}^{-4}\right]$ (initial value), $\mathrm{kp}$ is the parabolic oxidation constant $\left[\mathrm{g}^{2} \cdot \mathrm{cm}^{-4} \cdot \mathrm{s}^{-1}\right]$ and $\mathrm{t}[\mathrm{s}]$ is the time.

The increased thickness of the oxide layer leads to increased electrical resistance thereof, which is undesirable. Furthermore, the thickness of the oxide layer reached during the operation time of the SOFC should be as small as possible, this restriction applies automatically to the specific mass gain. This is because excessive growth of the oxide layer results in dimensional changes and facilitates their detachment

\footnotetext{
* Technical contribution to the 69th ABM International Annual Congress and to the ENEMET, July $21^{\text {st }}-25^{\text {th }}$, 2014, São Paulo, SP, Brazil.
} 


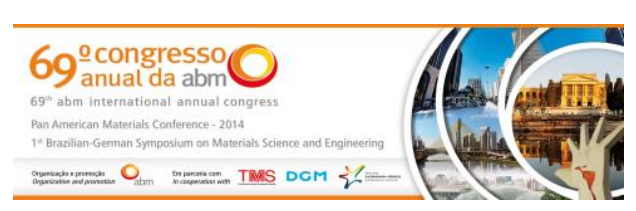

(spalling) of the substrate due to thermal stresses, causing blockage of air or fuel channels, as well as contamination of the electrodes. Based on this constraint, it is now considered that the parabolic oxidation constant at operating temperature should be less than $1 \times 10^{-14} \mathrm{~g}^{2} \cdot \mathrm{cm}^{-4} \cdot \mathrm{s}^{-1}$, and ideally less than $1 \times 10-15 \mathrm{~g}^{2} \cdot \mathrm{cm}^{-4} \cdot \mathrm{s}^{-1}$. These threshold values are derived from calculations of the thickness of the oxide layer after $40.000 \mathrm{~h}$ of operation [13] which is conventionally adopted for a target minimum SOFC lifetime [8-10].

Thus, according to the above considerations, it has been found that the use of the doped lanthanum chromites as component of composite coating was beneficial for FSS-based substrate interconnects with either $\mathrm{Ni}$ or $\mathrm{Cu}$ as metal-based coating. The $\mathrm{kp}$ values, obtained from the results shown in Figure 3 and by regression based on Equation 1 in Table 1 confirm these assertions, although improvements must be made to minimize the $\mathrm{kp}$, as well as long-term testing. This work is a preliminary study, which will give rise to new developments.

As a result of the growth of the oxide layer, related to the mass gain considered above, an increase in the electrical resistivity of the surface layer of the material of the interconnector occurs, resulting in increased electrical contact resistance between the components of the single SOFC unit and of all stack, causing loss of performance and efficiency. Thus, the ASR analysis of the interconnects is critical. According to the literature [8-10,13] is generally accepted that the ASR should not exceed $100 \mathrm{~m} \Omega . \mathrm{cm}^{2}$ in $40,000 \mathrm{~h}$ of operation. This limit comes from a target set by DOE (U.S. Department of Energy) in their SECA program (State Energy Conversion Alliance) for development of SOFC [14].

Table 2 shows the results obtained from area specific electrical resistance (ASR) measurements for up to 2,000 hours of exposure to the test samples by oxidation at $800^{\circ} \mathrm{C}$ in air for samples of AISI 430, AISI 441 and Crofer22APU ${ }^{\circledR}$ with and without coatings.

Summary, of the results shown in Table 2, it appears that, for all cases studied, the adoption of coatings to significantly reduce the values of ASR for time range considered. Similarly to the evaluation of mass gain, better results related to the minimization of the ASR were obtained with the Ni/Cu layers with LCSCM-2 and LCSCM-1 on Crofer22APU ${ }^{\circledR}$ systems, and then on steel AISI 441, to which the following system of $\mathrm{Cu} / \mathrm{CeO}_{2}-\mathrm{Crofer}_{2} \mathrm{APU}{ }^{\circledR}$, which also showed a low value of $\mathrm{kp}$ (cf. Table 1). Evidently, these findings are related because it is expected that the materials or interconnectors that have smaller mass gains (smaller thicknesses of oxide layers) also result in lower values of $A S R$, which in fact was evident in the results shown in Figure 3 and Tables 1 and 2.

In the studied systems, the ASR values obtained are similar to those obtained by Shaigan $[8,15]$ also with systems of this type and produced by electrodeposition, showing also that the oxidation resistance can be improved by dispersion of oxides (especially with lanthanum chromite) in nickel plating. Judging by the values given in Tables 1 and 2 this observation has a general character for all systems studied in this work and, even more to the use of multiple doped lanthanum chromites, which was not evaluated in the literature as a coating, although that improvements in process characterization and long term tests should be considered, as indeed occurs in the all works on metallic interconnects [8-13,15].

\footnotetext{
* Technical contribution to the $69^{\text {th }} A B M$ International Annual Congress and to the ENEMET, July $21^{\text {st }}-25^{\text {th }}$, 2014, São Paulo, SP, Brazil.
} 


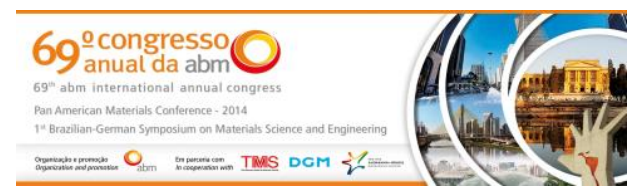

Table 2. Specific electrical resistance per unit area (ASR) for the studied systems

\begin{tabular}{c|c|c|c}
\hline & \multicolumn{3}{|c}{ Substrate - Ferritic Stainless Steel (FSS) } \\
\hline & AISI 430 & \multicolumn{1}{c}{ AISI 441} & Crofer $22 \mathrm{APU}^{\circledR}$ \\
\hline & & & \\
\hline Uncoated $\left(\mathrm{m} \Omega . \mathrm{cm}^{2}\right)$ & $59.8 \pm 5.2$ & $42.1 \pm 5.0$ & $28.2 \pm 2.9$ \\
\hline With the coatings below: & & & \\
\hline $\mathrm{Ni} / \mathrm{La}_{2} \mathrm{O}_{3}$ & $21.3 \pm 4.2$ & $17.2 \pm 3.6$ & $10.9 \pm 1.8$ \\
\hline $\mathrm{Ni} / \mathrm{CeO}_{2}$ & $18.4 \pm 4.0$ & $16.9 \pm 3.1$ & $12.4 \pm 3.1$ \\
\hline $\mathrm{Ni} / \mathrm{Y}_{2} \mathrm{O}_{3}$ & $23.5 \pm 4.3$ & $21.2 \pm 3.8$ & $15.9 \pm 2.0$ \\
\hline $\mathrm{Ni} / \mathrm{LaCrO}_{3}$ & $15.0 \pm 2.9$ & $11.6 \pm 2.0$ & $10.5 \pm 2.3$ \\
\hline $\mathrm{Ni} / \mathrm{LCSCM} 1$ & $14.3 \pm 3.1$ & $11.0 \pm 2.0$ & $9.6 \pm 2.2$ \\
\hline $\mathrm{Ni} / \mathrm{LCSCM}-2$ & $13,8 \pm 2.8$ & $9.1 \pm 1.6$ & $8.2 \pm 1.4$ \\
\hline $\mathrm{Cu} / \mathrm{La}_{2} \mathrm{O}_{3}$ & $21.2 \pm 4.9$ & $18.7 \pm 5.2$ & $14.4 \pm 5.2$ \\
\hline $\mathrm{Cu} / \mathrm{CeO}_{2}$ & $15.4 \pm 3.4$ & $12.0 \pm 1.8$ & $9.4 \pm 2.1$ \\
\hline $\mathrm{Cu} / \mathrm{Y}_{2} \mathrm{O}_{3}$ & $19.0 \pm 4.2$ & $14.1 \pm 2.5$ & $12.3 \pm 1.1$ \\
\hline $\mathrm{Cu} / \mathrm{LaCrO}_{3}$ & $16.2 \pm 3.2$ & $12.1 \pm 2.0$ & $11.2 \pm 2.2$ \\
\hline $\mathrm{Cu} / \mathrm{LCSCM}-1$ & $15.7 \pm 3.2$ & $11.5 \pm 2.5$ & $10.9 \pm 2.0$ \\
\hline $\mathrm{Cu} / \mathrm{LCSCM}-2$ & $15.1 \pm 2.7$ & $10.4 \pm 1.5$ & $9.7 \pm 1.6$ \\
\hline
\end{tabular}

From the results shown in Table 2, in general, we see that for the three substrates, occurs significant reduction of the ASR values (after 2,000 h) for all coatings when compared to its substrates without coatings, indicating that thus, all coatings considered in this work fulfill its basic function of preserving the FSS substrates throughout the aging time considered in this work. However, optimization certainly much remains to be considered, because after 2,000 hours, all the values of Table 2 are lower than $100 \mathrm{~m} \Omega . \mathrm{cm}^{2}$, but this time interval is twenty times lower than the minimum considered in the literature for SOFC stack testing as a whole.

Thus, the use of three-doped ( $\mathrm{Ca}, \mathrm{Sr}, \mathrm{Mg}$ ) lanthanum chromite (LCSCM-2) allowed improving characteristics of interest (notably reduce kp and ASR) compared to the use of non-doped $\left(\mathrm{LaCrO}_{3}\right)$ and mono (Sr)-doped lanthanum chromites (LCSCM-1) (as well as relative to lanthanum oxide, $\mathrm{La}_{2} \mathrm{O}_{3}$ ). These results may be of interest as a basis for new further developments, since it can circumvent the problems of low densification of the pure chromite (pure ceramic bodies, for purely ceramic interconnects), using them as components of composite coatings on metallic interconnects.

The improvement of the surface coatings of the interconnects is of great importance, since the ultimate goal of process optimization is to avoid the occurrence of failures in the coating process that can compromise the quality of obtained interconnects. The Figure 4 shows images of typical failures that can occur in cases of coated interconnects as considered in this work. It can be seen flaking off of the oxidation layer, disintegration, and lack of coating in the vicinity of an edge of the plate layer, and examples of rupture, fragmentation, and detachment of the coating. Figure 5 shows some photomicrographs on the surface samples of systems that, after the doped chromites, also showed good results of the thermogravimetric and electrical tests. It is noted, in all cases, the homogeneity of the surface, although with some porosity (observed, notably in Figures 5(a) and 5(c) Ni/CeO $2-C r o f e r 22 A P U, ~ C u / \mathrm{CeO}_{2}-$ Crofer22APU ${ }^{\circledR}$ ) and the appearance of precipitates (Figure 5(d), Ni/La2 $\mathrm{O}_{3}-\mathrm{AISI}_{441}$ ). Figure 6 shows images and EDS results of the Ni/LCSCM-2-Crofer22APU ${ }^{\circledR}$ system.

\footnotetext{
* Technical contribution to the 69th ABM International Annual Congress and to the ENEMET, July $21^{\text {st }}-25^{\text {th }}$, 2014, São Paulo, SP, Brazil.
} 


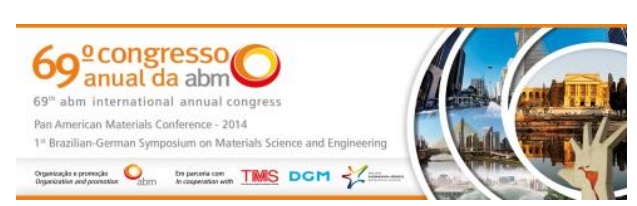

The metal-particle systems that showed better results in terms of minimizing the growth of the surface oxide layer and of reducing the area specific electric resistance were the nickel or copper based with particles of lanthanum chromites with multiple doping, La0.90 $\mathrm{Ca}_{0.05} \mathrm{Sr}_{0.05} \mathrm{Cr}_{0.95} \mathrm{Mg}_{0.05} \mathrm{O}_{3}$, on Crofer22APU ${ }^{\circledR}$ and AISI 441 steels. It is intended to act now on optimizing the coating process and evaluation with larger oxidation times.

\section{REFERENCES}

1 Cottrell CA, Grasman SE, Thomas M, Martin KB, Sheffield JW. Strategies for stationary and portable fuel cell markets. International Journal of Hydrogen Energy. 2011;36: 7969-75.

2 Blum L, Deja R, Peters R, Stolten D. Comparison of efficiencies of low, mean and high temperature fuel cell systems. International Journal of Hydrogen Energy. 2011;36: 11056-067.

3 Furtado JGM, Oliveira RN. Development of lanthanum chromites-based materials for solid oxide fuel cell interconnects. In: Proceedings of the $62^{\text {nd }}$ ABM Annual Congress; 2007; Vitória, Brazil. São Paulo: ABM; 2007.

4 Furtado JGM, Oliveira RN, Serra ET, Soares CM. Microstructural development and characterization of ceramics based on lanthanum chromite for use in fuel cell solid oxide. In: Proceedings of the XVII CBECIMAT; 2006; Foz do Iguaçu, Brazil.

5 Wincewicz KC, Cooper, JS. Taxonomies of SOFC material and manufacturing alternatives. Journal of Power Sources. 2005;140:280-296.

6 Sfeir J. $\mathrm{LaCrO}_{3}$-based anodes: stability considerations. Journal of Power Sources. 2003;118:276-285.

7 Choudhury A, Chandra $\mathrm{H}$, Arora A. Application of solid oxide fuel cell technology for power generation. Renewable and Sustainable Energy Reviews. 2013;20:430-442.

8 Shaigan N, Qu W, Ivey DG, Chen W. A review of recent progress in coatings, surface modifications and alloy developments for solid oxide fuel cell ferritic stainless steel interconnects. Journal of Power Sources. 2010;195:1529-1542.

9 Tondo E, Boniardi M, Cannoletta D. Electrodeposition of yttria/cobalt oxide and yttria/gold coatings onto ferritic stainless steel for SOFC interconnects. Journal of Power Sources. 2010;195:4772-78.

10 Wu J, Liu X. Recent Development of SOFC Metallic Interconnect. Journal of Materials Science \&Technology. 2010;26:293-305.

11 Dheeradhada VS, Cao H, Alinger MJ. Oxidation of ferritic stainless steel interconnects: Thermodynamic and kinetic assessment. Journal of Power Sources. 2011;196:1975-82.

12 Froitzheim J, Meier GH, Niewolak L. Development of high strength ferritic steel for interconnect application in SOFCs. Journal of Power Sources. 2008;178:163-173.

13 Cooper L, Benhaddad S, Wood A, Ivey DG. The effect of surface treatment on the oxidation of ferritic stainless steels used for solid oxide fuel cell interconnects. Journal of Power Sources. 2008;184:220-228.

14 DOE. Office of Fossil Energy Fuel Cell Program - 2012 Portfolio. Solid State Energy Conversion Alliance (SECA). DOE/NETL; 2012. p.116-124.

15 Shaigan N. Protective/Conductive Coatings for Ferritic Stainless Steel Interconnects Used in Solid Oxide Fuel Cells [doctor thesis]. Edmonton: University of Alberta; 2009.

\footnotetext{
* Technical contribution to the $69^{\text {th }} A B M$ International Annual Congress and to the ENEMET, July $21^{\text {st }}-25^{\text {th }}$, 2014, São Paulo, SP, Brazil.
} 